\title{
Unschooling and Indigenous Education
}

\author{
Noah Romero * (D) and Sandra Yellowhorse \\ School of Māori and Indigenous Education, University of Auckland, Te Puna Wānanga, \\ Auckland 1021, New Zealand; s.yellowhorse@auckland.ac.nz \\ * Correspondence: noah.romero@auckland.ac.nz
}

Citation: Romero, Noah, and Sandra Yellowhorse. 2021. Unschooling and Indigenous Education. Humanities 10: 125. https://doi.org/10.3390/ h10040125

Received: 1 October 2021

Accepted: 21 November 2021

Published: 6 December 2021

Publisher's Note: MDPI stays neutral with regard to jurisdictional claims in published maps and institutional affiliations.

Copyright: (c) 2021 by the authors. Licensee MDPI, Basel, Switzerland. This article is an open access article distributed under the terms and conditions of the Creative Commons Attribution (CC BY) license (https:// creativecommons.org/licenses/by/ $4.0 /)$.

\begin{abstract}
This article draws from autoethnography and historical analysis to examine how racialized people pursue educational justice, consent, inclusion, and enjoyment through non-hegemonic learning. A historical analysis of U.S. colonial education systems imposed upon Diné and Philippine peoples grounds a comparative study on two forms of anti-colonial pedagogy: Indigenous education and critical unschooling. These two lines of inquiry underpin autoethnographic analyses of our own experiences in non-hegemonic learning to offer direct insights into the process of experiential, and decolonial growth intimated in relational learning environments. Indigenous education and critical unschooling literature both affirm the notion that all learners are always already educators and students, regardless of their age, ability, or status. This notion reorients the processes and aspirations of education toward an understanding that everyone holds valuable knowledge and is inherently sovereign. These relational values link together to form systems of circular knowledge exchange that honour the gifts of all learners and create learning environments where every contribution is framed as vital to the whole of the community. This study shows that because these principles resonate in multiple sites of colonial contact across Philippine and Diné knowledge systems, through Indigenous education and critical unschooling, and in our own lived experiences, it is important to examine these resonant frequencies together as a syncretic whole and to consider how they can inform further subversions of hegemonic educational frameworks.
\end{abstract}

Keywords: Indigenous education; unschooling; decolonisation; Diné; Philippine

\section{Introduction}

This article examines the resonances between Indigenous education and critical unschooling - two forms of non-hegemonic pedagogy that centre experiential learning, inclusivity, and community engagement. Specifically, we reflect upon our own experiences in Indigenous education and critical unschooling through a historical analysis of how colonial education has impacted Navajo and Philippine peoples. Indigenous education can broadly be described as education for life which accounts for the "sacred roles of Nature, environment and community", the foundations of interconnectedness and the process of ever-evolving relationships (Cajete 2004, p. 29). Critical unschooling refers to a form of primarily home-based education which defines the pursuit of gender equity, community engagement, and social justice as the objective of education itself (Romero 2018, 2021). Recognising their common departure from the orthodoxies of Western educational philosophy, this study investigates the parallels, possibilities, and divergences between Indigenous education and critical unschooling to expand our understanding of anti-colonial pedagogy, or ways of teaching and learning and relating that resist the metastasizing violence of colonialism while honouring the aspirations of those doing the resisting (Zembylas 2020).

The pairing of these theoretical and deeply political frameworks became evident to us during our time as international PhD Candidates at the University of Auckland. Sandra Yellowhorse is a Diné writer who is interested in Indigenous knowledge systems, Diné intellectual pedagogy, and Critical Disability Studies. Noah Romero is a Filipino scholar 
whose work explores the liberatory potential of non-hierarchical learning. Through our political orientations toward decolonising praxis, community building, and anti-capitalist and anti-racist pedagogy, we conceptualise education as a life process infused with enjoyment and self-discovery. The parallels between our respective fields and research show how both critical unschooling and Indigenous education can speak to one another in generative ways. We do not conflate these two forms of education, nor do we argue that one can be read easily through the other. We are aware of the challenges that comparative analysis can create by engaging two worldviews with one another. We have both witnessed the impacts of certain methodological practices, particularly the potential of compartmentalizing vast knowledge systems in unintended, reductive ways through comparative work. However, our approach was anchored with awareness and intention to find resonance between our political stances towards anti-colonial education. We attempt to make these broad connections between our research fields, personal histories, and aspects of resonance between our cultural understandings that give shape to our political orientation in pursuing education as liberation. Our aim is to place these fields in conversation to envision culturally accountable educational philosophies that support the wishes, rights, and desires of all learners. In refuting homogenized approaches to comparative work, we speak for ourselves as two perspectives of two distinct and very different worldviews, through our understandings of these various intersections of history, cultural knowledge, experience, and engagement with the canons of our respective fields.

First, it is important to understand what Indigenous education inherently contests, along with some of the inequitable conditions that draw People of Colour to subcultural learning contexts like unschooling. Section 2 foregrounds this study in a historical analysis of the colonial provenance of mainstream, standardized, and normalized approaches to education, particularly in the United States. Because the autoethnographic sections of this study elucidate the specific ways we have encountered and resisted the legacy of colonial education, this historical scaffolding focuses on how U.S. imperialism specifically impacted generations of Philippine and Diné peoples. It is important to note that colonial education failed to eradicate the Indigenous lifeways of Diné and Philippine peoples, a fact that informs Section 3, which discusses the resonances between Diné and Philippine epistemology and lifeways. This act of theorising-as-remembrance grounds this article in the relational and ancestral theories of personhood, learning, and sociality that colonial schooling sought to undermine and replace. It also establishes the conceptual groundwork we apply in Section 4 to a comparative analysis of Indigenous education and critical unschooling, which we frame as forms of relational learning that can subvert the ongoing legacy of colonial education. Sections 5 and 6 present autoethnographic analyses of our own experiences in Indigenous education and critical unschooling. These narratives offer lived insights into how anti-colonial pedagogy can emerge out of relational autonomy and interdependence. By weaving historical, comparative, and autoethnographic analysis together to show how Philippine and Diné values can be remembered through relational and non-hegemonic learning, we seek to illuminate hopeful ways forward in the pursuit of life-affirming pedagogies rooted in kinship, communion, and solidarity.

\section{The Roots of Compulsory Schooling and the Need for Decolonial Approaches}

Scholars of historical education often argue that compulsory schooling serves to normalise imperialism and have explored the deep links between compulsory schooling and colonisation (Adams 1995; Lee 2018; Lomawaima and McCarty 2006). Schooling was integral to the emergence of the United States as a global empire in the early 20th century, when it occupied overseas territories like Guam, Puerto Rico, Hawai'i, and the Philippines (Constantino and Constantino 1982). Emphasising the moral value of thrift, entrepreneurship, and hard work, compulsory education in the US-occupied Philippines worked to naturalise the presumed supremacy of metropolitan American governance. While American Presidents like William McKinley and Theodore Roosevelt framed their exploits as civilising missions, the project of American imperial statecraft was founded in 
the same discourses that underpinned the genocidal birth of the United States: warfare, slavery, anti-black chattel racism, the extermination of Indigenous peoples (Lowe 2015), and the exploitation, scapegoating, and over-policing of nondominant groups. The role of compulsory education in American empire-building was to naturalise the ideals of American governance and its notions of supremacy (Grande 2004; Yellowhorse 2018a). While contemporary schools are contested spaces (Kawai et al. 2014), calls for liberatory forms of education ought not to overlook this history.

Indigenous peoples throughout North America have a long history of forced engagement with colonial education via the institution of boarding schools and legislation that mandated the separation of children from their communities (Haskie 2018; King 2018; Lee 2018). The normalisation of compulsory schooling severed young peoples' ties from family, community, and knowledge systems, thus furthering colonial projects rooted in U.S. imperialism. As an ideological state apparatus (Althusser 1977), or covert means of imposing social order, compulsory education manufactures consent by producing the illusion of meritocracy (Bowles and Gintis 1976). Indigenous knowledge systems, when judged by the rubric of 'merit' formulated by Western standards of being, knowing, and doing, were disregarded as recognized modes of 'valid' education (Lomawaima and McCarty 2006). Compulsory schooling sought to erase modes of learning which were grounded in land, community, and experience. Colonial schooling also made it so that education was no longer an every-moment endeavour, but something segregated and decontextualized. Education became a product rather than a process.

Physical removal and separation were not the only violent aspects of compulsory schooling. Another was the use of curriculum to force Indigenous peoples into assimilating into the White supremacist structures of Anglo-American dominant culture (Emerson 2014; Grande 2004). The schools' curriculum promoted American ideals like individualism and private property, which directly opposed Indigenous epistemologies and lifeways that centred communal ownership and the notion that land, waterways, and the cosmos were living and agentic entities that could not be possessed but must rather be looked after (Begay 2017; Emerson 2014; Cajete 2004). It is important to note that these pedagogies of assimilation are ongoing and reverberate beyond the decades of colonial schooling endured by Indigenous peoples. According to the late Larry Emerson (2014), a Diné educator and elder, these assimilative policies and curricula imposed foreign ways of doing and being while teaching young people to actively abandon ancestral knowledge:

I was taught by Christianity and public school people to view the Diné world negatively and as irrelevant. I was taught to deny my Diné identity, history, culture, language and politics. (p. 51)

The assimilative processes of colonial schooling were not only imposed; education itself became how Indigenous students learned to consent to and comply with the erasure of their identities, languages, and cultures. The violence of colonial schooling was not limited to the destruction of Indigenous knowledge: Indigenous life itself was erased within those halls. There is substantial evidence of horrific abuse and neglect now amplified in current investigations into Indian Residential Schools in Canada, which were modelled after U.S. boarding schools. Countless children died at these schools (Pember 2021), and they were often buried in unmarked, mass graves. Many are only now being discovered (Honderich). The governments of the United States and Canada often offer performative nods to these horrific abuses yet fail to substantially reform the colonial logics that continue to underwrite education systems and propagate the devaluation of Indigenous life and lifeways.

In 1863, the U.S. military undertook an act of ethnic cleansing known as The Long Walk, in which some 9000 Diné were forced to march 300 miles from their ancestral lands and were imprisoned at Fort Sumner (Denetdale 2016). Diné returned to their ancestral lands upon the signing of the Treaty of Bosque Redondo in 1868 (Parsons-Yazzie and Speas 2007). The Treaty did not promise that the U.S. would never pursue assimilation through other means: one of its conditions was that all Diné families would send their children aged 
6-16 years to an English school (Link 1968). According to Article VI of the Treaty of 1868, the purpose of this education was to "insure the civilization of the Indians entering into this treaty" (Link 1968, p. 21). Compulsory education became another form of Indigenous erasure as it removed children from home and land and relocated them into schoolhouses where they would learn from a curriculum that defined them as inferior and in need of civilising.

As their ancestral land had been shrunken and stolen, surviving colonial schooling for many Diné children meant jeopardising what remained of their identity: kinship ties, culture, and language (Haskie 2002). Separating children from their families and forcing them into government schools undermined the development of a culturally rooted sense of Diné personhood based on connections. The effects of compulsory education continue to be felt: Diné language, a crucial repository of Diné knowledge and tradition, is resurgent but remains threatened (Lee 2014). After nearly a century of operation, the enduring harms inflicted by the boarding school system began to be addressed on a system-wide basis in the 1970s, with the passage of the Indian Self-Determination Act. Even though some boarding schools remain, they are largely run by the tribes themselves, who only recently have regained the right to autonomously administer Indigenous schooling (Haskie 2013).

The U.S. exported its wartime strategy of assimilation and erasure through education when it acquired the Philippines from Spain in 1898. Colonial education in the Philippines, however, differed in observable ways from Indian boarding schools. By the early 1900s, the U.S. began pursuing a strategy of benevolent assimilation - the idea that the U.S. was occupying sovereign lands mainly to modernize them (Sintos Coloma 2016, p. 242). U.S. administrators, soldiers, and teachers mostly ascribed to the idea that the Philippines would have to earn its independence by demonstrating the tenets of Western liberal democracy and extractive capitalism to their satisfaction (Romero 2020).

Gleeck (1976) notes that U.S. education in the Philippines was underwritten by a doctrine of 'character building', which mirrored the U.S. boarding school system in ascribing moral value to Western models of individualistic productivity and property ownership whilst denigrating (and opposing it to) Indigenous knowledge (Yellowhorse 2018b). U.S. administrations were long grounded in the belief that Philippine peoples were intellectually, morally, and temperamentally unfit for self-governance. The 'character' that American educators sought to instil involved six values thought to be wholly foreign to the Philippine psyche: democracy, honesty, industry, thrift, sportsmanship, and patriotism (Gleeck 1976, pp. 29-32). This portrayal of Philippine peoples as an infantile, debased, and debilitated population provided rhetorical justification for the ongoing occupation of the Philippines. The U.S.'s system of compulsory colonial education thereafter continued to reinforce the notion that "these people were a conquered nation whose national life had to be woven into the pattern of American dominance" (Constantino and Constantino 1982, p. 5).

The prospect of decolonising education thus requires an examination of the colonising function of institutional schooling. From an Indigenous education perspective, that is, not only the removal of education from the community, home, and land context but literal removal of land from Indigenous peoples. As a Diné scholar, I conceptualize decolonisation according to the works of Tuck and Yang (2012) in that, "decolonization is not a metaphor", and that it has to do with the repatriation of land, and, therefore, the futurity of Indigenous life. According to Cajete (2015) "to understand Indigenous education, we must consider not only the community and culture, but also the land, which is actually the first and most essential teacher" (p. 46). Land-based learning, as instituted by Indigenous educators across North America, is indeed resurging. Paired with active movement building toward \#LandBack, the call to repatriate Indigenous land is part of the inherent process of Indigenous education from my perspective as a Diné educator.

Recognising the similar experiences of colonised people in the American empire illuminates the intentionality with which the U.S. sought to remake the world. However, a historical analysis of colonial schooling in occupied territories also shows the common ground upon which those targeted by genocidal U.S. statecraft might stand in solidarity 
with one another. As Philippine and Diné scholars, we find that the points of convergence between our respective cultures are indeed worthy of examination. The overlapping histories of colonialism in the Philippines and in Diné Bikéyah (Navajo land) do not only reveal shared traumas; they illuminate complementary connections between knowledge which we can draw from to envision decolonial pedagogies here and now. We explore some of these convergences in the following section, which looks to Philippine and Diné epistemology to proffer relational and reciprocal understandings of both learning and identity in defiance of colonial schooling.

\section{Points of Convergence: K'é and Kalayaan}

With the historical resonance across Diné and Philippine histories of schooling, some of the more interesting resonances we have encountered stem from the philological points of departure that inform our approaches to the function and purpose of learning. We provisionally refer to these as the primacy of relational autonomy in Philippine epistemology and interdependence in an Indigenous context, as informed by the work of Tewa scholar and educator Gregory Cajete (Cajete 2004, 2015). We underscore that these concepts are conversant but not necessarily analogous.

Relational autonomy refers to a sense of personal agency that is shaped by social contexts and relations that can both support and constrain individual agency (Davy 2019). Indigenous Philippine knowledge systems further contend that the ethical exercise of autonomy is achieved when one's actions are directed toward the well-being of the collective (Reyes 2015). In the Philippines, the word autonomy is translated to kalayaan, but psychologist Virgilio Enriquez (1989) argues that kalayaan differs from Western autonomy in fundamental ways. Autonomy, in English, refers solely to the capacity of an individual to do as he or she pleases. Kalayaan recognizes the importance of pursuing one's goals but adds that an individual's actions are only ethical if they are pursued in service to one's community. This distinction underscores the idea that the collective - not the individual-is the most important concern within Philippine epistemology:

The freedom to do a particular act or the lack of it determines whether a person or a community survives or perishes. The Aetas of Zambales simply have no choice but to move their kaingin fields every so often despite forestry laws to the contrary. The duck raisers of Laguna, in the same manner, must intrude into the fishpens of the bay to gather shells for their flock otherwise their livelihood will cease. (Enriquez 1989, p. 37)

Kalayaan is relational because the self is also shared. Enriquez (1989) argues that the overarching cultural value that unites all Philippine peoples, despite their religious and ethnolinguistic heterogeneity, is their belief in kapwa. Kapwa holds that one's identity is shared with all human and non-human others. One's self is so thoroughly distributed that all individuals are inherently responsible for the well-being of others. The acts of caring for one's community and caring for oneself cannot be separated in a kapwa-oriented society. The primacy of kapwa made it so that pre-colonial Philippine social life and identity both emerge out of a sense of loyalty and duty to one's barangay, a village comprised of people who are always, already, and unquestionably responsible for one another.

Cajete (2004) defines interdependence, or inter-relatedness, as "a spiritual orientation and responsibility for maintaining a conscious relationship with those things human life depended on for survival ... nothing in life could be viewed as purely self-sufficient, especially human beings" (p. 89). What is important to note from this description, is that it is not merely physical mutual dependence, but also a spiritual interdependence in which relationships become how we live, learn, and cultivate our completest sense of self (Cajete 2004). The tenets laid out in Cajete's foundations of Indigenous education further note that "integration and interconnectedness are universal traits of its contexts and processes" (p. 29). In other words, community and relationship are both the context for learning and the means for learning (Cajete 2015). 
While in no way a direct translation nor completely transferrable, kalayaan and kapwa resonate with Diné concept of $k^{\prime} e$. $K^{\prime} e$ refers to the Diné system of kinship, or positive relationships between people, land, places (Lee 2020). According to Diné scholar Lloyd Lee (2020) "K'é reinforces respect, kindness, cooperation, friendliness, reciprocity, and love" (p. 70). $K^{\prime} e$ is distinct from $K^{\prime} e i$, which are clan relationships through kinship (Lee 2020, p. 70). However, the foundational aspect of relational thinking and orienting are fundamental aspects of $k^{\prime} e ́$. Haskie (2002) further explains that $k^{\prime} e$ involves establishing similarly respectful relationships "with everything in the universe" (p. ii). According to Nez (2018), "the complex Diné belief system that everything has a place in the universe" (p. 17). In this way, $k^{\prime} e$ is both a practice and theoretical way of understanding, knowing, and living through relationship. It is a process of relating and, therefore, realising the inherent interdependence woven throughout the world.

As a Philippine scholar, I find that recognising the similarities between Philippine and Diné philosophy helps inform a sense of Philippine personhood that is untethered to neo-colonial assimilationist concerns about the Filipino's role in the U.S. society and racialized capitalism. Remembering the history of colonial schooling in the Philippines and finding similar memories in Diné Bikéyah reminds me Dylan Rodriguez's (2010) contention that the liberation of Philippine peoples will involve the pursuit of "lines of betrayal ... to a deformed nationalism" (p. 97) and "the insurgent production of ... Filipino collective historical memory that articulates from within the constitutive violence and traumatic rupturings of American conquest and colonization" (p. 48). This provocation informs this article's autoethnographic sections, in which we look to our experiences in non-hierarchical, relational, and non-hegemonic learning to examine how resistance and alternative paths forward can emerge from the remembrance of Indigenous lifeways, the refutation of colonial schooling, and the pursuit of Philippine-Dine solidarities. Before presenting these narratives, we foreground them in a discussion of the contemporary unschooling movement and its similarities with reciprocal Indigenous approaches to teaching and learning.

\section{Critical Unschooling and Indigenous Education}

A historically situated analysis of colonial schooling and the knowledge systems it sought to erase demonstrates how decolonial educational research is often limited by a focus on schools and school systems. Looking to the literature on both critical unschooling and Indigenous Education helps illuminate pedagogies that more directly counter the colonial architecture of compulsory schooling. Indigenous education and critical unschooling both view learning as a lifelong and relational process that revolves around understanding that the relationality between people, their environments, and communities are the ideal medium for facilitating learning. While Indigenous education and critical unschooling share some foundational commitments, they are not completely synonymous. However, placing these practices into conversation and relation promotes an understanding of how learning emerges from the inside out (through relationality) instead of being systemically imposed from the outside in.

Unschooling is a form of primarily home-based education that eschews teachercentred instruction, imposed curricula, assessment measures, and the bifurcation of knowledge into bounded disciplines (Riley 2020). The term unschooling itself was developed by the American author John Holt $(1995,2017)$, who argued that children learn best in unstructured environments and when they are encouraged to pursue their own interests (Grunzke 2010). Unschooling, per Larrichia (2016) "is about creating an environment that is conducive to real learning - not just for your children, but for everyone in the family, because learning is a lifelong activity" (p. 12). Unschoolers believe that learning is a never-ending process that occurs informally throughout the course of one's everyday life (Woodford 2020).

Alternative education, however, is not immune to hegemonic thinking and progressive educationalists have warned that privileging the needs of individual learners over the 
collective well-being of all students can undermine collective struggles for social justice in education (Lubienski 2000). Critical unschooling is a burgeoning approach to self-directed education that responds to these warnings in addition to the limitations of traditional unschooling discourse. Critical unschooling combines self-directed education with a call to reimagine society and the family to reflect and reproduce justice, harmony, and balance (Romero 2018, 2020). A praxis of critical unschooling entails three overarching political commitments:

(1) critically unschooling the self, or critically reflecting upon one's positionality and responsibilities to "leverage one's skills, privileges, passions, and abilities to act and educate in ways that transform" (Romero 2021, p. 68);

(2) queering the family, or interrogating and rooting out the patriarchal, heterosexist, and homophobic attitudes and behaviours manifested in one's family life to enable each family member to live in concordance with their authentic self; and

(3) decolonising self-directed education, or orienting the objective of unschooling away from the selfish pursuit of individual liberty toward the communal striving toward Indigenous futurity, or the notion that peace and sustainability are contingent upon our ability to practice racial and social justice along with protecting Indigenous land, people, and ways of being (Woodford 2020).

Similarly, Indigenous education has, since time immemorial, viewed experiential learning as a fundamental aspect of life processes, relations, family environment, and relationship with the land. Indigenous epistemologies view the development of individual identity as a promise of cultivating one's interests and skills grounded in a sense of inherent belonging in the larger community (Cajete 2015).

Indigenous education could resonate with the concept of self-direction through the principle that "the true sources of knowledge are found within the individual and the entities of Nature" (Cajete 2004, p. 30). It is important to note that the context of learning is often oriented through land, community, and cultural practices, not through the 'self' as it is in both unschooling and critical unschooling. Self-direction, in Indigenous education, reflects a more complex understanding of the 'self' wherein individuals are encouraged to develop their curiosity in the world as it relates to their gifts and interests as part of a greater whole. In other words, all individuals are recognized to have interests in specific things and pursuing these interests is encouraged by individuals to understand their roles and belonging as part of a community. Still, Indigenous education and philosophies of unschooling share common aspirations in that both emphasise enjoyment and inquisitiveness, rather than 'academic achievement,' performance, or rote memorisation, as key goals of education. Although Indigenous education is critical of the "English-American process of intense memorizing of facts and doctrines" (Cajete 2004, p. 12), it is important to note that Indigenous education does have a distinct pedagogy and form. These instead are determined by individual communities, their environment, and cultural teachings in what Cajete $(2004,2015)$ identifies as ritual or ceremonial life.

The concept of relational autonomy, which underpins much of what critical unschooling aspires toward, resonates with Indigenous educative frameworks of interdependence, which "integrates human individuality with communal needs" (Cajete 2004, p. 30). Both relational autonomy and interdependence recognise the individual in their own uniqueness and way of being. Practitioners of critical unschooling and Indigenous education are also concerned with the individual's greater relationship to a larger community and understand that education does not end with the decontextualised development of an atomised person. The unschooling emphasis on non-formal and self-directed learning could, thus, relate to experiential learning and resonate with what Cajete (2004) calls "learning through thinking and doing" (p. 31). This resonance can also be observed in the way critical unschooling eschews curriculum based on procedural and arbitrary tasks in favour of process pedagogies that emerge from a sense of mutual reciprocity between individuals, their families, and communities. 
A notable point of divergence between critical unschooling and Indigenous education is how each philosophy treats the notion of hierarchy. Unschoolers often argue that relationships between adults and children ought to be egalitarian, with children trusted to direct their learning while parents serve as mentors and guides rather than clear-cut authority figures (Gray and Riley 2013). Certain 'hierarchies' do, however, exist in Indigenous communities, as evidenced by the importance of land, environment, and ceremonial life through community. These 'hierarchies' are better understood as clear roles established throughout Indigenous communities, which confer certain status, respect, and prestige, particularly upon our elders (Cajete 2015). However, the special gifts of young and unique learners, such as those with dis/abilities, are also viewed as precious teachers. They carry special knowledge, gifts, and ways of being that contribute to the process of learning that all people can benefit from, even though they are seen to have different roles vis-à-vis their elders.

Indigenous education can, therefore, be theorised as being more concerned with nonhegemonic, as opposed to non-hierarchical, learning. The underlying aim of Indigenous education is the grounding of life-affirming relationships. This dynamic notably differs from a simply non-hierarchical one, in which learners might perform egalitarianism without thinking critically about the importance of engaged leadership or the benefits of positive role models and elders. Theorising the implications of unschooling's insistence on nonhierarchical learning through Indigenous education, thus, shows how unschooling can centre an independent conception of self instead of a shared or relational self.

The emphasis on humanistic agency found in unschooling also diverges from Indigenous education's understanding that the environment and community are the first educators. In Indigenous Community: Rekindling the Teachings of the Seventh Fire, Cajete (2015) examines how community is both "the medium and the message" (p. xvi). Drawing upon Environmental scholar David Orr's contention that, "schooling should not be confused with learning" (p. 17), Cajete (2015) argues that "education began not as an art or science, ideology or philosophy, but as a lifelong process of learning how to be in the world by participating in wider community life" (p. 13). In this sense, everyone possesses a "teacher within", who has a place, a face, and an important role and gift to contribute to the wider community. This observation demonstrates how deeply embedded Western individualism is in educational thought, even in spaces that purport to reject it. Exploring the complexities of both unschooling and Indigenous education conveys a provisional sense of where these praxes do and do not meet, along with a greater understanding of how they can critically engage with one another.

An interesting convergence point lies in the attention paid to discourses of dis/ability within Indigenous education and unschooling. According to Cajete $(2004,2015)$, Indigenous models of education and learning understand that everyone is already presumed to have something to teach others. Because of the inherent value that diverse perspectives bring to the realm of cyclic knowledge systems, Indigenous education recognises, honours, and utilises the skills, interests, and expertise of all individuals regardless of their ability. This idea further reshapes our understanding of community because it starts from a position where we understand that everyone has knowledge of different things. These understandings together form a system of circular knowledge exchange, that honours and brings forward the gifts of all learners.

Wayne Purcell (2019), an academic who also practices unschooling with children who experience disability, describes unschooling as a radical rejection of the traumatic bureaucracies they encountered in early childhood and primary education:

Our journey out of being complicit in our own oppression had begun. If this is what people with kids who experienced disability did, then we were moving out of the centre and finding the margins. The margins were always safe spaces where we could be free to discover new ways of being in the world. And the vision of Kenyon's future presented to us [by the school] was not a vision I was 
willing to accept. And our journey began with two of the most useful words I've

found in social justice work-fuck you. (p. 123)

The expertise of individuals with dis/ability is often labelled in Western discourse as negative behaviours and deficit-oriented traits through biomedical frameworks (Wong 2020; Hall 2011). These imposed and violent ideologies are dismantled in both Indigenous education and unschooling, as both hold the view that every contribution of expertise is vital to the whole of the community.

There is much resonance in the ways critical unschooling and Indigenous education literature view the institution of compulsory schooling. In Deschooling Society, a seminal text of the unschooling movement, Ivan Illich (1970) argues that most learning occurs casually, in the pursuit of one's interests and in conversation with others. Rather than fostering the interests and learning process of each individual, schools systematise, universalise, and regulate the infinitely variable process of learning. For Illich (1970), the inefficient way schools deliver education suggests that the primary role of the school is to justify its own existence. Illich (1970) argues that deschooling, or restructuring society around an appreciation for peoples' natural inquisitiveness and divesting from our dependence on compulsory schooling, is the responsibility of every inherently-sovereign individual. Practitioners and proponents of unschooling and critical unschooling, who seek to minimise their interactions with the surveillant apparatus of the school and the state, often endeavour to do exactly that. Similarly, Indigenous education relies on principles of inherent sovereignty, curiosity, relationship, and experiential learning. Indigenous education, therefore, has connective links that give shape to potential conversations between movements for critical unschooling and the resurgence of Indigenous knowledge systems. These conversations offer key pedagogical interventions that question the institution of systemised education in addition to its impacts on marginalised learners such as People of Colour (POC), and people with dis/ability.

While critical unschooling may not account for place-based and Indigenous ways of doing (Romero 2020), dismantling continued colonialism remains an active commitment and a universal responsibility. In other words, decolonisation is not the sole responsibility of Indigenous peoples. The prospect of decolonisation- or the gradual unlearning of colonial psychopathology (Fanon 2004), the foreclosure of hegemonic systems and settler epistemologies, the dislodging of homogenized, imposed, normative frameworks, and the repatriation of stolen land (Tuck and Yang 2012) —requires paradigmatic shifts in the conventional wisdom that allows colonial relations to be reproduced in social formations, including in our families. As such, unschooling cannot be considered decolonising by default simply because it rejects the influence of the school. Critical unschoolers should, thus, look to Indigenous education to ensure alternative education practices are oriented toward the pursuit of equity, justice, and the redress of historical wrongs.

However, what does it mean to experience decolonial consciousness-raising in a nonhegemonic learning environment? The following sections show glimpses of our own lives in critical unschooling and Indigenous education. The purpose of this exercise is to utilize narratives that show the effect non-hierarchical and non-hegemonic learning has on those who practice and pursue it. These narratives aim to show how home-based, reciprocal, relational, and resistive pedagogies enable Indigenous Peoples and diasporic People of Colour to reclaim the ancestral knowledge denigrated and damaged by the imposition of colonial schooling in our respective nations.

\section{Autoethnography of a Filipino-American Unschooler}

Living by intersecting commitments to critical unschooling and the liberation of the colonised Philippine subject involved learning that decolonisation starts from within. For me, this process entailed a transition from colonial subject to bayani, or warrior. In precolonial Philippine societies, bayani protected the barangay by warding off invaders and settling intertribal disputes. However, bayani also farmed, fished, and played with children. The breadth of a bayani's responsibilities showed that they did not attain an exalted rank 
solely by dominating others or hoarding wealth. Rather, they did so by modelling virtue and fostering communal well-being (Canlas n.d.). The work of a bayani parallels that of an unschooling parent as both look after the community's cultural and material well-being. Attempting to assume the warrior role in my unschooling barangay, however, has required confronting the intergenerational effects of colonialism and colonial education on my own sense of self.

Historian Jeffrey Milligan (2020) explains that in Maranao oral tradition, warriors were held responsible for passing on the tribe's knowledge to its young people. The responsibility of education fell to one who demonstrated the moral character required of a knowledge bearer, lest the community's knowledge be corrupted during the process of transmission. Maranao conceptions of 'education' were, as such, "expressed in the quality and nature of the individual's being rather than the quantity or quality of knowledge possessed" (Milligan 2020, p. 32). Being 'educated' in pre-colonial Philippine life was relational and reciprocal. Knowledge was the providence of the just, kind, and caringnot those who were simply learned. Developing an insurgent sense of contemporary Philippine identity through unschooling, for me, involves reconciling the reciprocal ethics of the barangay with a global capitalist superstructure that does not value, incentivise, or compensate any of these ideals.

Fulfilling the role of the bayani involves taking ownership over one's responsibilities and practising mindful and engaged leadership. This often comes into conflict with recurrent discourses in unschooling, where there is a distinct potential to emphasise unencumbered individualism when the beliefs that inform our everyday practices are not thoroughly interrogated. These pitfalls are evident in the terms used to signify some of the benefits of unschooling: self-discipline, self-regulation, and self-directed education itself (Ricci and Pritscher 2015). Moral discourses rooted in individualism also appear in how unschoolers approach video gaming and screen use: they often advocate unlimited consumption as a means of teaching self-regulation. While video games can impart valuable lessons about pattern recognition, storytelling, and teamwork, they are also often designed to be habit-forming and addictive. A relational approach to screen time and video gaming invites candid conversations about media consumption that can be rooted in evidence rather than dogma.

While there is undeniable value in learning something completely independently, my experiences as an unschooling mentor and guide have taught me that the importance of letting your loved ones know that they are seen, heard, and appreciated without condition. There is always time to read a book, go for a walk, throw a ball, tell a joke, learn a new skill, conduct a science experiment, build something, and to ask my partner and children how they are feeling. Unschooling helped me realise that I was never encouraged to do any of these things in school.

Answering the ancestral call of the bayani, however, does not mean patriarchally imposing my will. It instead means using my skills and privileges to enrich the lives of my family members and to bring us closer together. My unschooling journey could not have been possible without reconceptualising my own subjectivity and subverting stereotypes of the ineducable Filipino imposed upon my ancestors and passed down to me. Practising critical unschooling in a way that fulfils its liberatory promise required that I become kapwa and recognise myself in the kinship networks whose love, generosity, and genealogy allow me to hold my head high. My mission is not for recognition, representation, or the signifiers of consumptive success defined by imaginary communities like America or the Philippines. Instead, unschooling has allowed me to realise that my entire being is supported by the interconnected bonds of duty and care that hold me and my barangay together in balance and harmony.

\section{A Life of Learning: A Diné Narrative}

When I first encountered unschooling discourse, I did not immediately relate it to my experience as a home-schooled learner. It is worthy to note that not all home-schoolers are 
unschoolers, and not all home-schoolers practice tenets of Indigenous education. However, when I did begin my research in this field, I noticed that there were elements of both Indigenous education and unschooling in my upbringing.

When I was in the fifth grade, my parents decided to home-school me. I left the confines of a restrictive, unhappy, and oppressive private religious school and found safety and respite in my family home. This was the first resonance of Indigenous education that my parents gave me. They brought me home. My family and home would be the context and also the means through which I would learn.

We used a long-distance learning curriculum from another accredited religious school. However, I not only fail to remember much from that program, but I also was not fully committed to institutional learning at that time. I remember art and expressing myself through music, drawing, and play. I also learned about Marx and socialism when I was in the sixth grade. I thought, even at that young age, that everyone should share and that an ideal world would be where everyone had their needs met and no one suffered without. What I remember most is the time I relished with my parents. Both my mom and dad are artists. My father hailed from a family of famous Navajo jewellery makers. My mother was a weaver, painter, and could make anything from fabric. Being together with them during that time was a gift.

There are two important things I identify as relative to the principles of Indigenous education and unschooling during my time being home-schooled. The first was that I learned about $k^{\prime} e$ from this time home with my mom. For years I felt like she did not explicitly teach me much about my culture growing up, of course, by no fault of her own. The effects of ethnic cleansing (Denetdale 2020) still reverberate throughout our communities. The alienation and assimilation of our cultures are very much part of that. That is the living legacy of colonialism and the boarding school era. However, I later realised that she did indeed teach me about my Diné culture through doing and living the principles even if she never discussed them. Although she never distinctly told me, this is $k^{\prime} e ́$ and these are the teachings, she lived them. I learned $k^{\prime} e$ through witnessing my mother live this principle. She built and cultivated relationship wherever she went. She was an expert gardener and could keep a garden alive in the hot summers of the New Mexico desert. She had relationship with her craft, her art, the natural world, and her countless relatives we knew far and wide. She was the exemplar of how to relate and how to care for others. Because of her, I was brought into the worlds of so many different people.

I spent a significant amount of time with my mother and her parents-my grandparents. Because of this, I learned and developed a deep abiding respect for my elders. Some of my fondest memories are the times I sat listening to them all talk. I learned patience, empathy, kindness, respect, generosity, and the importance of who I was, and who I wanted to become through them. As a relational outcome, who I am is deeply influenced by the positive relationships I sustained with my mom and grandparents. They all were teachers whose values gave me a renewed sense of learning. It was loving, giving, reciprocal and beautiful. In this way, I felt like I had a beautiful education during those years. It was by no means perfect, and home-schooling involved its own unique challenges, particularly having been raised in a Christian setting, which I found deeply hierarchical and imposing. That is a story for another time. However, this time home with my parents and grandparents nurtured me in profound ways. In retrospect, being separated away from them in a schoolhouse could not have instilled the deep connection and way of relating I learned during that foundational time in my life.

The second important thing was the self-initiated learning and interest-driven aspect of my schooling. Although always offered the curriculum, I was more interested in larger philosophical questions at that time. My teenage self was tremendously thoughtful, and overwhelmed by how expansive the human mind could be. I concerned myself with deep philosophical questions at a young age. Yet, schooling fails to adequately create space for these questions and the deep, personal, and philosophical reflecting that takes place when given the freedom to explore these questions. Often students are kept distracted in their 
days with busy work and mundane tasks and are never given the opportunity to engage these big philosophical questions they have that are so important to figuring out who they are, or what their values and beliefs are for themselves.

During this time, I became I writer and kept journals. Reading and writing were not oppressive and meaningless exercises such as learning the conventions of essay writing and the structuring of topic sentences, introductions, body paragraphs, and conclusions. Instead, it was powerful writing and a means in which I not only learned to express myself but also developed the life-long habit of reflecting through writing and story. This was built on the back of growing up and always having my father read to us every night-a gift I have treasured my whole life.

Self-initiated learning occurred in organic, spontaneous ways. Sitting in our living room listening to music blast from my dad's workshop attached to our home, taught me about history and culture. I learned about jazz music — a favourite genre of his-the history of the great artists, their distinct styles and collaborations. I lived and learned through the mediums that were interesting to me and meaningful to my family. We bonded over them. They facilitated my learning and taught me that learning was a shared journey. Because of this, my relationship with music and history is positive and reciprocal. My learning was relational, and I learned to connect in countless ways within my home, family, and natural world.

My experience of being home-schooled influenced my life and philosophy in profound ways. I grew up in a state of play. I experienced enjoyment and self-discipline to cultivate my own learning and curiosity. Because of these traits I developed during my time being home-schooled, when I returned to public school in my sophomore year, I found myself an advanced student. It certainly was not because of all the rigorous lesson plans I had completed or that I was successful at hitting all the benchmarks in testing. It was because learning was something I loved. I learned to appropriate my appreciation for these to other, less-compelling topics because it was rooted in positive relationships to learning. Both Indigenous education principles and unschooling elements are found within my story. They give me the passion and belief that these aspects of learning can help cultivate a greater sense of learning and enjoyment that are so foundational in the movement for educational justice.

\section{Conclusions}

The year 2021 marks the five hundredth anniversary of Ferdinand Magellan's arrival in the Philippines-the beginning of the archipelago's colonial epoch. This article has sought to function as a provisional act of revisioning, remembrance, and connecting between histories of colonialism and the ongoing solidarities which rise to meet them. We trouble calls to decolonise education that diagnose the problems of pedagogies rooted in the coloniality of power but proffer solutions that stop at harm reduction or calls for earnest expansion of what is permissible within the confines of institutional and coercive learning environments. We call for decolonisation in ways that honour community, consent, and the invocation of sovereignty on multiple fronts. From a Diné stance, I call for decolonisation that includes movements for the repatriation of Indigenous land. To ignore the importance of land in relationship to Indigenous life is to ignore the foundational first step of educational planning and justice in Indigenous communities. I call for the end of these shallow attempts to mobilise the language of decolonisation without the substantial, committed movement to cultivate and have control over our learning environments, which is the land.

We draw from a critical historiography of the U.S.'s attempts at ethnic cleansing and epistemic erasure in the Philippines and in the Diné Nation, which purposefully sought to harness the methods and mechanisms of compulsory schooling to eradicate Indigenous knowledge systems. Throughout this analysis of Philippine and Diné educational history, we remind readers our peoples resisted colonial attempts to pathologize, disenfranchise, and debilitate them. We theorised alternative paths forward suggested by the praxes of unschooling and Indigenous education to remind scholars that historically colonised 
and Indigenous peoples have built entire worlds by honouring our own cosmologies, lifeways, kinship ties, and ancestors. We rebuild our worlds with power and foresight by upholding ancestral knowledge systems that foster liberating education and inspire horizontal solidarities in the global struggle to get Indigenous lifeways and land back once and for all.

Author Contributions: Conceptualization: N.R.; methodology, N.R. and S.Y.; formal analysis, N.R. and S.Y.; writing - original draft preparation, N.R. and S.Y.; writing-review and editing, N.R. and S.Y. All authors have read and agreed to the published version of the manuscript.

Funding: This research received no external funding.

Institutional Review Board Statement: Not applicable.

Informed Consent Statement: Not applicable.

Acknowledgments: Sandra: I express my gratitude to Te Puna Wānanga, at the University of Auckland. This program gave me the opportunity to build global solidarity as an Indigenous person. My profound thanks to Gregory Cajete, and all our Indigenous relations. The collective writings of Indigenous peoples have helped me imagine an educational future by looking to Indigenous lifeways, where all children are celebrated and belong. Noah: I give thanks to my family and the students and faculty at the Center for Indigenous Peoples Education at the Nueva Ecija University of Science and Technology in the Philippines.

Conflicts of Interest: The authors declare no conflict of interest.

\section{References}

Adams, David Wallace. 1995. Education for Extinction: American Indians and the Boarding School Experience, 1875-1928. Lawrence: University Press of Kansas.

Althusser, Louis. 1977. Lenin and Philosophy, and Other Essays. London: NLB.

Begay, Manley. 2017. The path of Navajo Sovereignty in traditional education: Harmony, disruption, distress, and restoration of harmony. In Navajo Sovereignty: Understandings and Visions of the Diné People. Edited by Jennifer Denetdale and Lloyd Lee. Tucson: University of Arizona Press, pp. 57-90.

Bowles, Samuel, and Herbert Gintis. 1976. Schooling in Capitalist America: Educational Reform and the Contradictions of Economic Life. New York: Basic Books.

Cajete, Gregory. 2004. Look to the Mountain: An Ecology of Indigenous Education. Rio Rancho: Kivaki Press.

Cajete, Gregory. 2015. Indigenous Community: Rekindling the Teachings of the Seventh Fire. St. Paul: Living Justice Press.

Canlas, Melissa. n.d. Filipino Community Portrait. Wildflowers. Available online: http://www.wildflowers.org/community/Filipino/ portrait.shtml (accessed on 15 October 2021).

Constantino, Renato, and Letizia Constantino. 1982. The miseducation of the Filipino. Quezon City: Foundation for Nationalist Studies.

Davy, Laura. 2019. Between an ethic of care and an ethic of autonomy. Angelaki 3: 101-14. [CrossRef]

Denetdale, Jennifer. 2016. “No Explanation, No Resolution, and No Answers": Border Town Violence and Navajo Resistance to Settler Colonialism. Wicazo Sa Review 31: 111-31. [CrossRef]

Denetdale, Jennifer. 2020. Refusing the gift of democracy and embracing Diné concepts of kinship: The Navajo Nation, citizenship, and practices of gender. Theory $\mathcal{E}$ Event 23: 1053-65. Available online: http://ezproxy.auckland.ac.nz/login?url=https: / / www.proquest.com/scholarly-journals / refusing-gift-democracy-embracing-diné-concepts/docview / 2456264100/se-2? accountid=8424 (accessed on 25 November 2021).

Emerson, Larry. 2014. Diné Culture, Decolonization and the politics of Hózhó. In Diné Perspectives. Tucson: University of Arizona Press.

Enriquez, Virgilio. 1989. Indigenous Psychology and National Consciousness. Tokyo: Institute for the Study of Languages and Cultures of Asia and Africa.

Fanon, Frantz. 2004. The Wretched of the Earth. New York: Grove Press.

Gleeck, Lewis. 1976. American Institutions in the Philippines, 1898-1941. Manila: Historical Conservation Society.

Grande, Sandy. 2004. Red Pedagogy: Native American Social and Political Thought. Washington, DC: Rowen and Littlefield.

Gray, Peter, and Gina Riley. 2013. The challenges and benefits of unschooling, according to 232 families who have chosen that route. Journal of Unschooling \& Alternative Learning 7: 1-27.

Grunzke, Rebecca. 2010. Pedagogues for a New Age: Childrearing Practices of Unschooling Parents. Ann Arbor: ProQuest Dissertations Publishing.

Hall, Kim. 2011. Feminist Disability Studies. Bloomington: Indiana University Press.

Haskie, Miranda. 2002. Preserving a Culture: Practicing the Navajo Principles of Hózhơ' Dóó K'é. Ann Arbor: ProQuest Dissertations Publishing. 
Haskie, Miranda. 2013. Teaching sociology at a tribal college: Navajo philosophy as a pedagogy. The American Sociologist 44: 378-84. [CrossRef]

Haskie, Miranda. 2018. Ripple effects: Intergenerational ties of Diné boarding school experience, stories and memories. Paper presentation at the Diné Studies Conference, Tsalie, Arizona, October 25-27.

Holt, John. 1995. How Children Fail. Reading: Addison-Wesley.

Holt, John. 2017. How Children Learn. New York: Lifelong Books.

Honderich, Holly. 2021 Why Canada Is Mourning the Death of Hundreds of Children. BBC News. Available online: https:/ /www.bbc. com/news/world-us-canada-57325653 (accessed on 15 October 2021).

Illich, Ivan. 1970. Deschooling Society. New York: Harper \& Row.

Kawai, Roi, Stephanie Serriere, and Dana Mitra. 2014. Contested Spaces of a “Failing" Elementary School. Theory E Research in Social Education 42: 486-515. [CrossRef]

King, Farina. 2018. Boarding School Conversations. Window Rock: Department of Diné Education.

Larrichia, Pam. 2016. What Is Unschooling? Living and Learning without School, Kindle ed. Ontario: Living Joyfully Enterprises.

Lee, Lloyd. 2020. Navajo Identity in a 21st Century World. Tucson: University of Arizona Press.

Lee, Tiffany. 2014. If I could speak Navajo, I'd definitely speak it 24/7": Diné youth language consciousness, activism, and reclamation of Diné identity. In Diné Perspectives: Revitalizing and Reclaiming Navajo Thought. Tucson: University of Arizona Press.

Lee, Tiffany. 2018. Ripple effects: Intergenerational ties of Diné boarding school experience, stories and memories. Paper presented at the Diné Studies Conference, Tsalie, Arizona, October 25-27.

Link, Martin. 1968. The Navajo Treaty 1868. Las Vegas: KC Publications.

Lomawaima, Tsianina, and Tersa McCarty. 2006. To Remain an Indian: Lessons in Democracy from a Century of Native American Education. New York: Teachers College Press.

Lowe, Lisa. 2015. The Intimacies of Four Continents. Durham: Duke University Press.

Lubienski, Christopher. 2000. Whither the common good? A critique of home schooling. Peabody Journal of Education 75: 207-32. [CrossRef]

Milligan, Jeffrey. 2020. Islamic Identity, Postcoloniality, and Educational Policy: Schooling and Ethno-Religious Conflict in the Southern Philippines. New York: Palgrave Macmillan.

Nez, Vangee. 2018. Diné Epistemology: Sa'ah Naaghai Bik'eh Hozhoon Teachings. Ph.D. dissertation, University of New Mexico, Albuquerque, NM, USA. Available online: https:/ /digitalrepository.unm.edu/educ_llss_etds/92/ (accessed on 21 October 2021).

Parsons-Yazzie, Evangeline, and Margaret Speas. 2007. Diné Bizaad Bínáhoo'aah: Rediscovering the Navajo Language. Flagstaff: Salina Bookshelf.

Pember, Mary Annette. 2021. Canada, U.S. Differ on Boarding Schools. Indian Country Today. Available online: https:// indiancountrytoday.com/news / canada-u-s-differ-on-boarding-school-policies (accessed on 15 October 2021).

Purcell, William. 2019. Holding Tight to the Tail of a Shooting Star: An Autoethnography of Unschooling as Just Education. Order No. 27547537. Available from Publicly Available Content Database. (2342583908). Ann Arbor: ProQuest Dissertations Publishing.

Reyes, Jeremiah. 2015. Loób and kapwa: An introduction to a Filipino virtue ethics. Asian Philosophy 25: 148-71. [CrossRef]

Ricci, Carlo, and Conrad P. Pritscher. 2015. Holistic Pedagogy: The Self and Quality Willed Learning. Heidelberg: Springer.

Riley, Gina. 2020. Unschooling: Exploring Learning Beyond the Classroom. New York: Palgrave Macmillan.

Rodriguez, Dylan. 2010. Suspended Apocalypse: White Supremacy, Genocide, and the Filipino Condition. Minneapolis: University of Minnesota Press.

Romero, Noah. 2018. Toward a critical unschooling pedagogy. Journal of Unschooling and Alternative Learning 12: 56-71.

Romero, Noah. 2020. Postcolonial Philosophy of Education in the Philippines. Oxford Research Encyclopedia of Education. Oxford: Oxford University Press. [CrossRef]

Romero, Noah. 2021. Toward a critical unschooling praxis. In Global Perspectives on Home Education in the 21st Century. Edited by Rebecca English. Hershey: IGI Global, pp. 65-75. [CrossRef]

Sintos Coloma, Roland. 2016. Becoming a problem: Imperial fix and Filipinos under United States rule in the early 1900s. Postcolonial Directions in Education 5: 241-64.

Tuck, Eve, and Wayne Yang. 2012. Decolonization is not a metaphor. Decolonization, Education and Society 1. Available online: https://jps.library.utoronto.ca/index.php/des/article/view/18630/15554 (accessed on 25 November 2021).

Wong, Alice. 2020. Disability Visibility: First Person Stories from the 21st Century. New York: Vintage Publishing.

Woodford, E.D. 2020. Indigenous ways of teaching and learning as unschooling: Relevant studies and contemporary and indigenous definitions of unschooling. Journal of Unschooling and Alternative Learning 14: 1-19.

Yellowhorse, Sandra. 2018a. The heart of K'é: Transforming Diné Special Education and Unsettling the Colonial Logics of Disability. Master's thesis, University of New Mexico, Albuquerque, NM, USA. Available online: https://digitalrepository.unm.edu/amst_ etds /61/ (accessed on 25 November 2021).

Yellowhorse, Sandra. 2018b. Ripple effects: Intergenerational ties of Diné boarding school experience, stories and memories. Paper presented at the Diné Studies Conference, Tsalie, Arizona, October 25-27.

Zembylas, Michalinos. 2020. Affective and biopolitical dimensions of hope: From critical hope to anti-colonial hope in pedagogy. Journal of Curriculum and Pedagogy. [CrossRef] 